\title{
HISTORICAL AND ETHNOGRAPHIC RESEARCHES OF TURKESTAN SCIENTIFIC SOCIETIES (ON THE BASIS OF NAU FUNDS)
}

\section{Azizbek Y. Nazarov}

Senior Lecturer, Department Of Source Studies And Archival Studies, Faculty Of History, National University Of Uzbekistan

\section{ABSTRACT}

This article reveals the content of documents in the collections of funds I-69, I-361, I-591, stored in the National Archives of Uzbekistan (NAU) of scientific societies in Turkestan, which provide historical and ethnographic information in terms of archival sources. The article examines the results of historical and ethnographic data of many scientific expeditions organized by scientific societies in the late XIX - early XX centuries and gives general conclusions.

KEYWORDS: - National Archive of Uzbekistan (NAU), archival source studies, archive, fund, collection, document, historical, ethnographic, expedition, research, report.

\section{INTRODUCTION}

Documents of the National Archives of Uzbekistan, reflecting the historical and ethnographic research formed as a result of the activities of scientific societies in the Turkestan region, help to objectively study the history of the region. The main goal of the Central Asian Scientific Society, engaged in such research, was a comprehensive study of the country [1].

Fund I-591, stored in NAU, according to the 1st collection. The first meeting of the Society was held in November 1869. Baron A.V. Kaulbars' report on his trip to the Tien Shan Mountains was heard. Several of them have also been published [2]. Also, G.A. Kolpakovsky's account of ancient finds in the south-eastern part of IssykKul was read out [3].

The program of "readings" in closed meetings of the society consisted of 9 sections and was approved by K.P. Kaufman on February 26, 1871[4].

\section{THE MAIN FINDINGS AND RESULTS}

A.S. Tatarinov's study plan "Mining, development history, current state and future in Turkestan" aims to enter Asia to acquire gold-rich countries, and the main purpose of mining was to study the mineral resources of the country. The negative effects of gold production in the Turkestan region have been studied through a scientific study of the formation of gold deposits, which is mainly carried out. At the same time, mining (coal) production in the country was established[5].

According to archival documents, the Imperial Society of Oriental Studies was founded on February 29, 1900, at the initiative and with the 
CURRENT RESEARCH JOURNAL OF HISTORY 2(11): 63-67, November

2021

DOI: https://doi.org/10.37547/history-crjh-02-11-13

ISSN 2767-472X

(C2021 Master Journals

Crossref doi

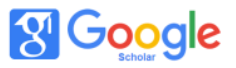

Accepted 25 $5^{\text {th }}$ November, 2021 \& Published 30 th November, 2021

approval of the Ministry of Finance of the Russian Empire. The minutes of the meeting of November 27, 1904 provided information on the activities of the Tashkent branch of the Society of Oriental Studies for 3 years after its establishment. The report notes that learning Russian in evening classes for adults in Tashkent has been effective. But the department also taught Oriental languages among Russians.

The issue of learning local languages was relevant to both military and civilian institutions in the region. At the same time, other institutions are required to learn local languages. In this regard, classrooms were set aside, where military meetings were sometimes held without disturbing teachers and students.

It was noted at the meeting that the number of members of the department is small, and volunteers and regional leaders interested in the fate of the Tashkent branch of the Society of Oriental Studies were invited to the next general meeting.

According to the minutes of the meeting, council member Saidkarim Saidazimbaev said that there were many students in local schools who were fluent in Russian and that there was no secondary school for them to continue their education. The council approved the statement, but stressed that the local population should be satisfied with the work done so far [6].

From the data of the above meeting, it can be said that the society focused on teaching the Russian language to the indigenous population, as well as increasing the number of members from the representatives of the region who benefited the society.

In a letter to the Governor-General of Turkestan on September 14, 1909, he spoke about the 8year activity of the Tashkent branch of the Society of Oriental Studies. In particular, in
1902-1903, evening courses were organized for those who wanted to learn Turkish and Persian. Oriental language courses were paid and soon closed due to lack of funds for those who wanted to learn the language.

In 1905, it was planned to open one of the lower schools in Tashkent for those who wanted to learn Uzbek Turkish, but due to the turbulent political situation at that time, evening courses for those who studied the language were not opened. In 1905, by order of the former chairman of the department, General K.V. Sakharov, the department was suspended due to various political movements.

From 1901 to 1907, Russian language courses were opened in five Russian schools in Tashkent at the expense of funds allocated by the Tashkent branch of the Society of Oriental Studies and the Council of the Society of Oriental Studies. These courses have been a great success. Among those who wanted to learn Russian from the locals, the majority were adults. During these years, more than 50 books and pamphlets by N.A.Ivanov, N.P.Ostroumov, A.A.Divaev and others were accepted as gifts to the department. A special commission headed by N.P. Ostroumov studied the introduction of Russian language teaching in madrassas and the establishment of educational institutions for Oriental languages in Tashkent. The department tried to establish a commercial educational institution in Tashkent, but these issues were not resolved.

I-361-fund List 1 List 5 contains information on the dwellings and conditions in which the population lives. According to the document, the local buildings did not meet the sanitary-hygienic requirements by the Europeans. Local buildings rarely have windows, lit by doors or windows. Even in small rooms, the installation of 2 or 3 windows that allow the flow of outside air was convenient for storing fresh air, but on the other 
CURRENT RESEARCH JOURNAL OF HISTORY 2(11): 63-67, November

2021

DOI: https://doi.org/10.37547/history-crjh-02-11-13

ISSN 2767-472X

(C2021 Master Journals

Crossref doi

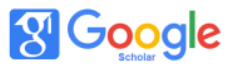

Accepted $25^{\text {th }}$ November, 2021 \& Published $30^{\text {th }}$ November, 2021

hand caused some inconvenience. With a sharp drop in outside air in winter and late fall, closing doors and windows with paper was also found to be unsatisfactory, as the paper provided very little protection from the cold on the outside and low light transmission on the other. Locals used sandals to heat their homes.

According to some documents, the school students were of different ages. Usually 7-8 to 16 years old, but there were even 4 year olds in school. They came with their brother or sister because they didn't have a caretaker. There were also adults over the age of 16 in the schools, who usually assisted the teacher in teaching [8].

School rules were the same in all local schools. Students gathered from 8 to 9 in the morning and studied for 2-3 hours. The youngest students went home in the afternoon, while the adults continued their studies after the break. There was no specific course of study in the schools and no exact number of students. The teacher went to school to teach one book, and the parents paid the teacher a small amount of money to switch to the second book. This amount ranged from 20 tiyn to 2 rubles, depending on the financial situation of the parents. The attitude of the teachers towards the students was good.

School buildings were also built like local houses, with heating stoves.

In addition to studying and publishing scientific works, the Tashkent branch of the Society of Oriental Studies, which operated from 1901 to 1913, from time to time organized the study of Oriental languages, lectures on oriental studies, exhibitions. Research work was carried out by members of the society N.P.Ostroumov, G.M.Gramenitsky, N.G.Mallitsky, I.I.Krauze, I.D.Yagello, M.I.Brodovsky. In 1902-1904, under the chairmanship of N.P. Ostroumov, a special panel discussed the introduction of the Russian language in madrassas. At the initiative of the society, a 2nd grade Russian-language school was opened [9].

In addition to conducting research, members of the society engaged in all kinds of activities have been the main helpers in sending to Russia the unique oriental manuscripts and material treasures collected from the country.

Many Russian scientists are known for their scientific research in Turkestan. For example, in 1908-1909, V.L. Vyatkin managed to open the Ulugbek Observatory through a foundation given by a local literary critic Abu Said Makhsum.

Subsequent analysis of the documentation of the composition of the funds shows that among the expeditions of the Turkestan branch of the IRGS were carried out for ethnographic purposes. The study of Turkestan from an ethnographic point of view is one of the main tasks of the Turkestan branch of the IRGS, which is stated in the charter of the society. To accomplish this task, the Turkestan branch council of the society assisted in conducting ethnographic research by organizing expeditions, publishing the most interesting works, and compiling reports at general meetings.

The activity of the Turkestan branch of the IRGS (1897-1917) is also noteworthy. This section was partially funded by the state. He is allocated 2,000 rubles a year. By the end of its second year, the IRGS Turkestan branch had 85 full members. In 1897, the society organized 3 expeditions. In particular, V.F. Oshanin - to Khojand, Jizzakh and Tashkent districts, P. Dyakov - Issyk-Kul, Ya.P. Gulyatov - to the Fergana region. They gave interesting information about the results of their expeditions at community meetings. Yana N.F. Sitnyakovsky's "Attempts to register the population in Bukhara", I.I. Geyer's "Report on a Journey Through Southern Bukhara in 1897," O.A. Shkapsky's lectures on "Agriculture in the Khiva and Amudarya" were also heard. 
CURRENT RESEARCH JOURNAL OF HISTORY 2(11): 63-67, November

2021

DOI: https://doi.org/10.37547/history-crjh-02-11-13

ISSN 2767-472X

(C2021 Master Journals

Crossref do

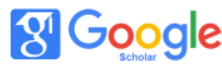

Accepted 25th November, 2021 \& Published 30 th November, 2021

The issues discussed at the meetings of the Turkestan branch of the IRGS were on various topics: 42 on zoology (21.5\%), 27 on lakes, rivers and glaciers (13.5\%), bibliographic and scientific-chronic documents - 20 (13\%), protocols $20 \quad(10 \%)$, information on ethnography, archeology and language - 14 (7\%), history $8(4 \%)$, geology (3.5\%), seismology 3 $(1.5 \%)$ ) listened to the lecture.

In 1909-1910, the department sent expeditions to Iliorti, Alatov, Namangan districts, the eastern shores of the Aral Sea, and the Turkestan ridges. As a result, E.S. Dmitriev's "Preliminary Report on the Journey to the Iliorti Alatov Glacier", N.A. Zarudny's "Journey to Southeast Bukhara", A.S. Galkin's "The Importance of the Occupation of Tashkent in the History of Russia's Arrival in Asia". E.V. Vasilevsky's "The basis of public education in the Turkestan region in the last half century", A.L. Schwartz's "Public health in Turkestan for the last 50 years" [10].

The department cooperates with many other scientific societies and individual scientists, including the IRGS and its Caucasus, Eastern Siberia, Western Siberia, the Emirate, as well as the Russian Academy of Sciences, the Society of Naturalists at the Universities of St. Petersburg, Kharkiv, Kazan, Novorossiysk, Warsaw, the Central Statistical Committee. , The Scientific Council, the Caucasus Museum, the Finnish Scientific Society, the Royal Geographical Society in London. The Society's library is a book fund, which in 1914 had 4,100 volumes of books.

The Turkestan branch of IRGS is one of the leading companies in the field of both scientific activity and publication of scientific works.

Volumes 8a, 29a, 31, 35a, 42, 53, 54, 62, 63, 64, 65 , which are currently stored in the I-69 fund, contain information on ethnographic research conducted by members of the society [12]. Also, among the documents kept in the 3rd collection of this fund are information about the expeditions of the Russian historian and ethnographer in Central Asia, Vice-Governor of the Syrdarya region I.I. Geyer (1860-1890) at the meeting on February 6, 1897. In particular, ethnographic data on the territory of East Bukhara, the economy of the population of the Karshi oasis and the transition from nomadic to sedentary life are given [13].

The following members of the IRGS Turkestan branch were mainly engaged in ethnographic matters: N.G. Mallitskiy, N.F. Sitnyakovskiy, N.A. Benderskiy, A.A. Divaev, P. Kuznetsov. From ethnographic works, A.A. Divaev's "Kyrgyz allasi", N.G. Mallitsky's "Song of Sart" was published, N.F. Sitnyakovsky Genealogical Tables of the Kyrgyz Family in the Fergana Region and the Uzbek Family in Kungrad, N.A. Bendersky compiled an ethnographic map of Turkestan (unpublished). These main works were compiled not on the basis of special ethnographic expeditions, but on the basis of materials collected during other studies. Only P. Kuznetsov conducted several special ethnographic expeditions to study Tajiks in Tashkent, Namangan and Kokand districts.

\section{Conclusion}

The analysis of data on historical and ethnographic research conducted by scientific societies in Turkestan is based on materials collected by expeditions to study the country in the field of science. The main authors of this information were also the leading representatives of the industry as well as the military serving in the imperial structures.

\section{REFERENCES}

1. NAU I-591-fund, 1st list, 3rd collection, 5th page. 
CURRENT RESEARCH JOURNAL OF HISTORY 2(11): 63-67, November

2021

DOI: https://doi.org/10.37547/history-crjh-02-11-13

ISSN 2767-472X

(C)2021 Master Journals

Crossref dof 81 Google

Accepted 25th November, 2021 \& Published 30 ${ }^{\text {th }}$ November, 2021

2. Nazarov, A. Y. (2019). THE FUND OF NATIONAL ARCHIVE OF UZBEKISTAN ABOUT THE SCIENTIFIC INSTITUTIONS IN TURKESTAN. Theoretical \& Applied Science, (10), 587-589.

3. NAU I-591-fund, 1st list, 1st collection, back page 1-3.

4. NAU I-591-fund, list 1 , collection 6 , back sheet 2-2.

5. Nazarov, A. Y. (2020). SCIENTIFIC SOCIETIES IN THE TURKESTAN GOVERNORATE-GENERAL AS AN INSTRUMENT OF COLONIAL STATEHOOD (ARCHIVAL SOURCE STUDY). Journal of Critical Reviews, 7(7), 1068-1073.

6. NAU I-361-fund, 1st list, 4th collection, 3rd page.

7. NAU I-361-fund, 1st list, 10th collection, 9th sheet.

8. НАЗАРОВ, А. Ё. (2021). ЎЗБЕКИСТОН МИЛЛИЙ АРХИВИ И-5 ФОНДИДА ЗАРАФШОН ВОХАСИДА ОЛИБ БОРИЛГАН ИЛМИЙ ИЗЛАНИШЛАРНИНГ АКС ЭТИШИ. In Uzbek Conference Publishing Hub (Vol. 1, No. 01, pp. 185189).

9. NAU I-361-fund, 1st list, 10th collection, 8th sheet.

10. NAU I-69 fund, list 1, collection 61, sheet 307.

11. Nazarov, A. (2020). History of The Emergence And Development Of Scientific Societies In The Governor-General of Turkestan. The American Journal of Social Science and Education Innovations, 2(10), 82-88.

12. Nazarov, A. Y. (2020). Analysis of historical and geographical research conducted in the governor-general of Turkestan. ACADEMICIA: An International Multidisciplinary Research Journal, 10(11), 858-863.

13. NAU I-69 fund, list 1 , collection 3 , sheets 14.

14. Назаров, А. (2021). ТУРКИСТОН ҚИШЛОҚ ХЎЖАЛИГИ ЖАМИЯТИ ФАОЛИЯТИ ТАРИХИДАН (ЎЗМА И-103 фонди асосида). ВЗГЛЯД В ПРОШЛОЕ, $4(2)$. 